\title{
The Challenges Faced by Graduates of Teacher Professional Education Program
}

\author{
Lilis Nur Hidayati ${ }^{1}$, Utami Widiati ${ }^{1}$, Enny Irawati ${ }^{1}$ \\ ${ }^{1}$ Pendidikan Bahasa Inggris-Universitas Negeri Malang
}

\section{INFO ARTIKEL}

\section{Riwayat Artikel:}

Diterima: 20-12-2019

Disetujui: 16-12-2020

Kata kunci:
professional education program;
narrative research;
pendidikan profesi guru;
penelitian naratif

\section{Alamat Korespondensi:}

Lilis Nur Hidayati

Pendidikan Bahasa Inggris

Universitas Negeri Malang

Jalan Semarang 5 Malang

E-mail: lilisnurhaa@gmail.com

\begin{abstract}
ABSTRAK
Abstract: This article gives a report on a study on the challenges faced by graduates of Teacher Professional Education Program in terms of lesson planning, execution stage, and evaluation. Narrative research is used for this study to understand present real-life experiences. The study revealed that the graduates of PPG experienced some challenges in those three phase of teaching and learning process; however, along with those challenges, they were able to give responses which they thought to be the most effective responses.
\end{abstract}

\begin{abstract}
Abstrak: Penelitian ini melaporkan hasil penelitian tentang tantangan yang dihadapi oleh lulusan Program Pendidikan Profesi Guru dalam merencanakan pembelajaran, mengimplementasikan rencana pembelajaran, dan evaluasi pembelajaran. Penelitian naratif digunakan untuk memahami pengalaman nyata dalam kehidupan. Penelitian ini mengungkapkan bahwa lulusan program PPG mengalami beberapa tantangan dalam ketiga tahapan pembelajaran tersebut, namun bersama dengan itu, mereka mampu memberikan respons yang menurut mereka paling efektif untuk dilakukan.
\end{abstract}

In an endeavor to ensure the betterment of teachers' education quality in Indonesia, the Indonesian government through the Ministry of Education and Culture in collaboration with the Ministry of Research, Technology and Higher Education has arranged a policy that becoming a professional teacher needs to join teacher professional education program (Pendidikan Profesi Guru-henceforth PPG). It is an intensive one-year program involving workshop-based courses that run five days a week, eight hours a day and requires 36-40 credits for the program completion (Widiati \& Hayati, 2015). The program is held intensively over two semesters, one semester for Subject-Specific Pedagogy (SSP) workshops and the other one semester for teaching internships and action research.

Since 2013, PPG program, especially for English teachers, has been launched in various forms such as in-service PPG, pre-service PPG, and SM3T PPG-teaching in the frontier, outermost, and disadvantaged regions in Indonesia. All of them are intended to overcome various kinds of education problems, such as: (1) shortage of teachers especially in the outermost, foremost, and disadvantaged regions, (2) unbalanced distribution, (3) unqualified teachers, (4) incompetent teachers, and (5) discrepancies between education qualifications and mismatched fields (Ministry of Research, Technology, and Higher Education, 2017). By the notion of improving the quality of education through improving the quality of educators professionalism that is recognized as the most strategic and decisive step (Fauzan \& Bahrissalim, 2017), PPG brings such an optimistic answer.

Some studies have discussed the advantages of taking part in PPG program as an attempt to educate teachers to be more competent and professional. According to (Triwinarni, 2016), PPG is believed to be effective in developing knowledge as well as familiarizing the participants with the latest technology. Catching up with the technology development will be beneficial for both teachers and students for example in choosing relevant materials, creating interactive media, and promoting assessment efficiency. It is in line with Law No. 12/2012 article 17 verse 1 on Higher Education that becomes one of the foundations of establishing PPG program stating that professional education is higher education taken after a degree or an undergraduate program that develops or prepares the student-teachers in occupations that require special abilities (Ministry of Research, Technology, and Higher Education, 2017). Furthermore, related to Triwinarni's finding, Umar et al., (2018) advocates that because there is a Subject Specific Pedagogy (SSP) workshop in the beginning of semester, the PPG students are provided by a supplies of material deepening and practical training either for devices creation, which is also technology, and/or microteaching and teaching practicum in partner school as well. In the micro-teaching, the student teachers are accompanied by the lecturer who acts as an observer. By the presence of supervising teachers or lecturers, both in micro-teaching and sometimes in the teaching practicum classes, the student teachers get valuable and meaningful suggestion and time allotment for consultation 
(Hidayah, 2013). In addition, Umar et al., (2018) and Adnyani (2015) strongly advocate that supervising teachers who observe directly and accompany the participants during the micro-teaching can criticize the obstacles which allow the student teachers aware of their mistakes. For the teaching practicum in the partner school, the PPG students will not only focus on teaching strategies, but also on how to build a good relationship with administrator and school officers. It is important due to the quality of education that carried out in schools largely depends on the cooperation of teachers and school directors (Aslanargun, 2015; Öztürk \& Yildirim, 2013). Moreover, in the study entitled Professional Development for Pre-Service Teacher, Adnyani (2015) asserts that professional education program is crucially needed as a tool to prepare the teachers candidate to be more sensitive towards the students' need based on their characteristics and background. It is then believed to be able to strengthen the PPG students' teaching skills in the aspects of mastery of learning tools and mastery of material (Fauzan \& Bahrissalim, 2017). As a result, all those various activities are logically intended to increase the student teachers' performance quality in terms of pedagogical, personality, professional, and social competences, which are directly related to the learning outcomes of the students (Hakim, 2015).

Refering to the positive responses towards the implementation of PPG aforementioned, unfortunately, the government does not have any resposibility for the next phase after the program completion, which means that the development or progression of PPG graduates has never been professionally tracked down and remain unknown. It is then limited to the assumption that those who have participated in PPG are confirmed to be a professional teacher without knowing how their process in English Language Teaching lives, in which part of teaching process they face challenges, and how they respond the challenges. As it is indicated in PPG Guideline Book (Pedoman Penyelenggaraan PPG) that the evaluation and monitor are (limitedly) done to see whether PPG is well-conducted including the preparation process, realization/implementation, and the results of PPG students examination: performance test, local writing test, and national writing test (Ministry of Research, Technology, and Higher Education, 2017).

Whereas, the transition into the English teacher after a period of time learning is often a difficult and challenging experience for newly graduated teachers (Flores \& Day, 2006; Huberman, 1989). The teachers' challenges cover mostly the three stages of the teaching process: planning, implementing, and evaluating (Al-Azzeh \& Yahya, 2011). In the planning issues, a study conducted by Widiati, Suryati, and Hayati (2018) elaborates that the newly graduated teachers complain about the complication of the 2013 curriculum-based lesson plans and most of them admit that they design the lesson plans based on the sample lesson plans prepared without comprehending the stages and the purpose of the lesson plan. The similar argument appears from Amin and Rahimi (2018) who strongly advocate that a newly graduate teachers have difficulties in lesson planning. They also find the challenges in the implementing process that the teachers have difficulties in implementing the curriculum in accordance with the classroom level and the allotted time (Amin \& Rahimi, 2018; Widiati et al., 2018). Moreover, Öztürk and Yildirim (2013) successfully discover the newly graduate teachers' issue in implementing process which includes classroom management in which nearly half (47\%) of them consider classroom management as the most challenging part of the career, typically or always. Akcan (2016), Amin and Rahimi (2018), Dickson et al., (2014), Liu (2014), and Senom et al., (2013) also put classroom management as the most struggling time to deal with their students' behavior. In the end, it makes them move away from their earlier classroom management ideas where they become more flexible adjusting to the classroom circumstance. Likewise, Widiati et al., (2018) find an issue in classroom management including difficulties in handling big classes. In some cases, the issues concerning the students include lack of interest in learning process, misdeed, lack of discipline, and negative attitudes towards learning English which are going to be more demanding (Akcan, 2016). Akcan (2016) in his exploratory case study also finds that the majority of the newly graduate teachers are not familiar with students with learning disabilities or behaviour problems. Most of them are confused on how to adjust the lessons and choose the context-specific teaching methods based on differences between individuals and groups (Amin \& Rahimi, 2018). In addition, as the third stage, students' learning evaluation or assessment is also an issue, especially in administering school-based assessment in which they affirm that they need teacher trainings (Senom et al., 2013). Widiati et al., (2018) add that student evaluation and scoring processes are demanding as most of the teachers participated in the research have many classes with a great number of students in each class.

According to the challenges experienced by the teachers in the three stages of teaching process above-mentioned, the researcher intends to uncover whether the PPG graduates face the similar issues. As PPG offers more workshops and intensive programs, the PPG graduates should be more ready to face the ELT lives. Therefore, the purpose of this study is to explore the PPG graduate English teachers' challenges during their initial years of teaching that they are really experiencing after taking bachelor program in ELT and joining the PPG program. As Indonesian government has assigned Universitas Negeri Malang to be one of univestities holding PPG program, this study will manage 21 graduates of SM3T PPG program UM 2016 (graduated in 2017) and 25 graduates of pre-service teachers PPG program UM 2017 (graduated in 2018).

Eventually, the literature which has been reviewed universally shows various aspects or dimensions of the non-PPGgraduate teachers' adaptation challenges, but the studies in PPG graduates are few and limited in scope. Therefore, a more comprehensive study of those dimensions appeared to be needed with teachers from different program. Accordingly, the main purpose of the present study is to examine: (1) the challenges faced by PPG graduates teachers and (2) how they respond to the challenges in terms of lesson planning, execution stage, and evaluation. With the help of this study, it provides information to all parties in charge of professional education or training for teachers. 


\section{METHOD}

Narrative inquiry is chosen as the best design of a research to address the research questions. Canadian researchers Connelly and Clandinin (1990) first use the term narrative inquiry to describe an already evolving approach to teacher education that focuses on personal storytelling. This type of research makes it possible for the researchers to understand experience (Bell, 2002). It helps researchers to collect information that people are not aware of themselves. The analysis of the people's stories can make it possible to expose deeply hidden assumptions. It spaces shaped windows in which participants could recover their own perception of others different from themselves (Mitton-Kükner, Nelson, \& Desrochers, 2010). In addition, exploring the past experiences of the participants is essentially to understand the composition of their identities in order to recognize the value of putting one's personal and professional identity within the temporal context of a life experience as a way of connecting the teacher's knowledge with the present context (Connelly \& Clandinin, 1990; Mitton-Kükner et al., 2010).

According to Polkinghorne (1995) as cited in Benson (2014), there are two forms of narrative inquiry: analysis of narrative and narrative analysis. They sound similar, but the analysis of narrative is more likely to analyze the participants' stories which are often analyzed using content or thematic analysis, while narrative analysis is analyzing the nonnarative data using storytelling or narrative writing. Since the present study applies content or thematic analysis, it then adopts the first form of narrative inquiry namely analysis of narrative.

The research participants are graduate students of PPG SM3T 2016 and pre-service teachers PPG 2017 in Universitas Negeri Malang. The participants are varied in terms of gender, IPK score, and background university. They have successfully completed the program after a year and come to their own hometown starting their career. The differences among the participants are believed to produce various kinds of interesting story patterns.

Since the objective of this narrative research study is to capture individuals' detailed stories, it is best to select a fewer number of participants (Creswell, 2013). In the process of choosing the participants, the researcher conducts preliminary study to find the most suitable praticipants. There are 21 students who joined PPG SM3T program and 25 students who joined preservice teachers PPG program. However, in order to make the study more relevant, participants are selected utilizing purposeful sampling that exerts some criteria for the participants in which they should:

- $\quad$ be the graduates of SM3T PPG 2016 and pre-service teachers PPG 2017,

- $\quad$ have been teaching continuously after graduating.

As this study is narrative inquiry, participants are willing to share extensive information about practical issues in their first year teaching and how they respond to the challenges (Creswell, 2013). Therefore, the number of the research participants may be completed or decreased since it depends on whether they meet the criteria and their agreement to be the participants.

\section{FINDINGS \& DISCUSSION}

Some theories have mentioned the fundamental phases of teaching and learning process. One of which belongs to Maheshwari (2012) who affirmed that there are three phases of teaching including planning stage (pre-active phase), execution stage (inter-active phase), and evaluation (post-active phase). In this part, the findings and discussion will be presented under those three phases as the themes/pattern.

\section{Challenges in Planning}

Planning is a major move that reminds the teacher what to do in the classroom. Preparation and planning matter as an investment that will 'pay off' in the long run, from the start to the end of the process of teaching and learning. There are actually no standard formats of what lesson planning should contain, however, Brown (2001) stated that there are several essential elements that should be included in the lesson plan: setting the goals, determining the objectives, choosing the activities, selecting media, and assessments.

Reflecting on the Brown's theory, the results of this research indicated that the research participants only experienced challenges in one element of the lesson planning purposed by Brown, that is selecting the media. Besides, the participants expressed that they also faced the challenges in terms of different lesson plan formula followed by the school and choosing suitable strategis; which will be discussed one by one in this section followed directly by how they respond to those challenges.

\section{Challenges in Selecting Media}

The first challenge experienced by the PPG graduates teachers was in line with one of Brown's lesson plan elements which is selecting media. In this case, five participants specifically shared an issue in terms of financial issues especially for selecting non-digital media since it needed some materials. They stated that some of non-digital media required some money, for example preparing big book, printed cards, snakes-and-ladders-based board game for the whole class, etc. P1, for instance, stated:

I am a honorary teacher and gets very limited salary. Sometimes school does not provide the materials for media making which we (the teachers) purpose, so I need to spend my own money that I think it is actually not a big problem, but if it happens continuously for many classes, I think it would be better if the school can provide the materials or budget allocation which the teachers need. 
P1's statement clearly shows one of the teachers' problems in Indonesia, teacher welfare. In fact, the welfare of the teacher is one of encouragement or motivation for improving the quality and performance of the teachers in order to improve the quality of education in Indonesia (Sulisworo, Nasir, \& Maryani, 2016), but many teachers, especially the honorary teachers, have not received decent salary that causes them to teach under some limitations. The afore-mentioned condition then obligates the teachers to look for the appropriate response in order to maximize the learning process and outcomes. There is a response offered by the participants that is enganging the students to take part in the process of selecting and making.

Although nowadays teachers may prefer digital media utilization which offers simplicity for some reasons and considerations, but sometimes teachers still need to bring the non-digital media or printed media into the classroom. In this case, according to the participants, it is possible to conduct task distribution, for example in making story pyramid, some students are required to bring papers, some of them bring marker, and the others bring pictures or crayons. Besides distributing the role for each student, they also practice to have a sense of responsibility for their own task. It is believed that sharing role and responsibility contributes to positive emotion outcomes and stronger overall relationships between teachers and students, as well as between students (Sierra, 2010). That is why it is highly possible that sharing responsibility in selecting and making media brings positive impacts such as minimizing cost, building up good relationship, and maximizing the learning outcomes.

In addition, as it has been slightly mentioned above, talking further about teachers' welfare, Sulisworo et al., (2016) in their research entitled Identification of Teachers' Problems in Indonesia of Facing Global Community suggested that to overcome the problem of teachers' welfare, the government needs to eliminate problems of large wealthy disparities and inequality rights among teachers with different salaries, to realize allowances of other teachers on time, and to increase salary or stipend for honorary teachers with minimum regional pay.

Upon meeting government-regulated qualifications and showing good commitment and quality in their teaching process, teachers are entitled to ask for their rights controlled in Law No.14/2005 Article 14-19. Teachers are deserved to receive: income above minimum cost of living and social welfare insurance, promotion and reward based on their performance, protection and intellectual property rights, opportunity to improve their skills, access to facilities and infrastructures to support teaching and learning processes, to make assessment and decision on students' graduation, reward, and/ or punishment as the principles of running ethics and constitution, to get comfortable feeling, security and assurance of safety on duty, freedom to obey profession organization, an opportunity to take part in educational policy, opportunity to improve academic qualifications and skills, and opportunity to obtain workshops and professional development in their fields.

\title{
Challenges in Dealing with Different Formula Lesson Plan
}

The second challenge was related to the different formula of lesson plan. There were 8 participants thought that the challenge in lesson planning was that the school where they are now teaching follows different formula as they had been studied in PPG program. As expressed by P2:

\begin{abstract}
The former school, where I taught for 4 months in teaching practicum of PPG program, believes that the scientific approach is necessary while the current school do not since every year the format is change. It takes some times for me to understand the different pattern when I start teaching in the school where I am teaching right now. I keep asking to myself, "which point I should include and should not?", or "do I need to write every single thing in detail? What kind of procedure do I need to follow?"
\end{abstract}

P2's statement shows that there are some different formula of lesson plans followed by every school. Fortunately, every participant has his/her way to respond to the challenge of different lesson plan formula: having some consultation with senior teachers, re-reading PPG materials, and changing the point of view.

P2 stated that being a new teacher needs senior teachers' supports, so he took some consultation sessions with his senior teachers. The senior teachers are considered as the experienced teachers committed to ongoing professional learning and high quality teaching. According to Tsai (2015), many years teaching experience of senior teachers are associated with their comprehensive experience, which in any way could be meaningful for the new teachers. Furthermore, in designing lesson plan the senior teachers can act as the advisor since they tend to be more knowledgeable of the circumstances and possibilities of the context (Rodrigues et al., 2018). Therefore, it can be said that senior teachers may give insightful suggestion for lesson planning.

Moreover, P3 added that everything comes from the teachers' mind in which they should always have a positive thought. It means that the teachers need to change their perspective towards the responsibility of creating a lesson plan. According to Omolara and Adebukola (2015), teachers' attitude can influence their performance positively and negatively; negative attitude towards a responsibility results in the negative performance, and vice versa. They stated that there is a misleading thought that the lesson plan is only one of responsibilities of teachers, so it sounds like more demanding that it should be. Therefore, the teachers should fix this kind of idea at the very first place since actually a lesson plan allows the teacher to move smoothly from one stage to the next and keeps the students engaged and motivated to work on the lesson's steps. It would be easier for the teachers, rather than putting it on the list of teachers' assignments. 
Besides changing point of view, some participants stated that re-reading the PPG materils is very beneficial. P4 stated, “When I was a PPG student, I was 'trained' to get used to unstoppable learning and unlimited-work-like that kept coming everyday. We made many kinds of lesson plans in different formats, since our lecturer gave us examples of lesson plan while at the same time the school where I coducted the teaching practicum fortunately also gave me an example. We also got workshops about lesson planning, so I usually read my notes again." P4's answer is likely to give a suggestion especially for the PPG graduates to remember what they have learned in PPG classes. It shows the advantage of PPG program, which is also mentioned by Widiati and Hayati (2015) in their research that PPG program has exposed the student teachers intensively with Subject-Specific Pedagogy (SSP) workshops, teaching internships and action research. Therefore, the graduates of PPG program may look the materials back to give appropriate response towards the challenge in different lesson plan formula followed by the school.

There have been actually some studies related to this kind of dillema, whether to follow which rule or manual. There is one that brings such a 'fresh air' for the teachers that according to Richards and Bohlke (2011) there is no rigid formulas for lesson plans, as what constitutes an effective lesson depends on many factors, including the content of the lesson, the teaching style of the teacher, the learning preferences of the students, the size of the class, and the learners' proficiency level. The lesson plan should reflect the expectations of each teacher regarding the nature of teaching and learning, knowing the content of the lesson, the role of the teacher in the lesson, and the approach or methodology that the teacher plans to implement.

In addition, according to Boikhutso (2010), different formula is in fact more likely to pose a dilemma and uncertainty about how student-teachers plan and implement the daily pedagogical routine of the teaching-learning process. However, he added that it does not matter if every school has its own manual in creating lesson plan, as long as the teachers understand the most important attributes of lesson plans and planning is that they add value to teaching and classroom instruction (Boikhutso, 2010). The important point in lesson planning is having clear understanding of overall objectives which help teachers concentrate on a stable set of tasks they design, thus reducing the amount of time needed to generate new ideas for the next day's class (Snow \& Campbell, 2006), no matter how the formula is.

\section{Challenges in Choosing Suitable Strategy}

The third challenge in lesson planning based on the findings is choosing suitable strategy. Choosing suitable strategies is one of the requirements before conducting the teaching and learning process. It is because the teachers need to know the materials and adjust which strategies that effectively support the process. According to Camp (2011), if someone wants to be the effective teacher, in order to facilitate student learning, he / she should be able to make wise choices about the most effective teaching methods to use and model the classroom curriculum. The strategies used define whether the students engage to the materials. Here, there are 5 participants who experienced a challenge in choosing suitable strategies due to some reasons.

Three participants stated that it is not easy to choose which strategy that is most suitable to deliver materials because they need to consider their students' personality and needs. The heterogeneous class seems to be the common issue faced by the teachers since there is no such thing as a 'homogeneous' class, since no two learners are really similar (Nusrat, 2017; Ur, 2009). There are different factors such as learning skill, motivation, aptitude, learning ability, background, learning experience, learing style, mother tongue, etc. According to (Nusrat, 2017), language classroom always consists learners of mixed ability even though the learners are in the same level. Therefore, the classroom activities need to be designed in such a way that it is neither too demanding for the weak learners nor unchallenging for the more competent learners.

Furthermore, the rest pointed out that choosing the strategy needs to consider the facilities of the school. For the school that only has limited facilities in terms of technology-based tools, some teachers (if they are not able to find the interactive strategy) usually will focus on using the coursebook. A good coursebook is able to promote good learning since it carries with it built-in structural scaffolding that ensures certain desirable outcomes even in situations where teachers are not prepared, not reflective, untrained, and indifferent (Ahmed, 2017). However, according to Zohrabi, Torabi, and Baybourdiani (2012), the strategy by only using coursebook is believed to be a traditional method that is still applied by most of the teachers in many countries.

In terms of the challenge in choosing suitable media as the third challenge in the lesson planning, the participants offered 4 responses: conducting classroom observation, preparing various strategies, utilizing the internet, and being adaptive towards the classroom situation. P5 affirmed that he conducted the classroom observation, sometimes spreading out the questionnaire, and having the students' reflection session. Spreading out the questionnaire demonstrates a teacher's effort to really understand the students. Basically, students appreciate a teacher who takes an interest in their likes and dislikes, their difficulties and their special interests. It allows them to feel comfortable while at the same time the teachers get the opportunity to observe them more closely on their personal level. In addition, reading students' reflection, the teacher can discern the students' feelings, difficulties, needs, and interest. Knowing those things help teachers in deciding the strategies for the next meeting. It is one of the ways to build a good relationship with the students.

Facing heterogeneous learners, since students can be diverse based on so many factors, it is better to accept the diversity and plan the lessons according to individual learners need for optimal learning (Nusrat, 2017). They can take advantage of the difference between students to organize the lesson. It becomes an inspiration for the teacher to arrange various kinds of activities. According to Pango (2015), it is essential to implement varied, cooperative, comprehensive, and diversified 
strategy. It means that teachers should be aware of the students' needs and interest which in the end can help them to prepare different kinds of strategy to avoid the feeling of boredom. It is in line with Hollins (2011) explanation in her research that the most important aspect of teaching and learning is how well the teacher knows the learner.

Related to the previous paragraph, some participants advocated that preparing various strategies is surprisingly helpful in which each activity may evoke the interest of different students. According to Nusrat (2017), using a variety of techniques and grouping strategies and a selection of self-assess materials can be the effective alternatives for the teachers to help all students be successful, comfortable for at least a portion of each class time. It shows that preparing more than one strategy is intended to a form of encompassing and giving similar attention to all of the students.

Furthermore, some participants believed in the advantages of internet utilization. The exponential growth of internet has given a considerable impact on language teaching and learning. Many teachers have utilized the internet for resource searching; whether from the credible journals or from the experts. A research conducted by Dogruer et al., (2011) found that a majority of the teachers who participated in the study used online resources and applications to support language teaching and choosing the strategy as they perceived that they lived in a world of resources and information at their fingertips. He stated that it indicates that there is an increasing likelihood that information is shared and received regardless of hierarchies by people from almost all walks of life through the use of modern technologies. The internet provides not only social connection and entertainment, but also academic and scientific information as well. Moreover, todays teachers worldwide are encouraged and expected to implement Information and Communication Technology (ICT) in instruction (Brändström, 2011; Gibson \& Oberg, 2004). Additionally, a research by Brändström (2011) also found that all the teachers who become the participants conceded that the internet is an additional teaching resource especially in planning.

However, the development of the internet requires the teachers to be really selective for which sources are credible and suitable with the learning objectives. It also requires media literate teachers, in which they need to be able to control over the unlimited information offered. It is because teachers operating with a high level of media literacy will have a strong, broad perspective where they actively use a set of highly developed skills to place a media message inside the context of a wellelaborated knowledge structure and are able to interpret any message along different dimensions (Pinto, Festas, \& Seixas, 2016). Therefore, beyond the process of analyzing, selecting, and evaluating, the teachers can wisely choose the best sources from the wide ocean of the information offered.

Last but not least, some of the participants suggested that the teachers have to be adaptive towards the classroom condition. Being an adaptive teacher here reflects the flexibility of teachers in problem-solving and decision-making towards any differences or challenges happen in teaching and learning process in which the strategy arranged in the lesson plan could be very adaptive based on what happens in the classroom. That is why there is a notion that teaching is a complex and inherently unpredictable task that requires high cognitive flexibility and a capacity for quick problem solving (Feldon, 2007; Kunter et al., 2013).

Based on the findings in this part, it is found that the research participants are no longer experiencing the challenges of setting the goals, determaining the objectives, choosing the activities, and assessment. However, they still experienced the challenge in selecting media, dealing with different formula of lesson plan, and choosing suitable strategies. No experiencing the challenges in some elements purposed by Brown (2001) may indicate that they have sufficient lesson and training in terms of those elements in their undergraduate and PPG program. The findings also show that the PPG graduates teachers have their own way to give the most effective responses based on their consideration.

\section{Challenges in Execution Stage}

The execution stage, which is usually called as the implementation stage, is basically where the learning experiences are provided to students through suitable modes. All the activities performed by the teachers after entering in a class are clubbed (to combine together) under the execution stage or inter-active phase of teaching (Maheshwari, 2012). These activities are generally concerned with the presentation and delivery of the content in a class. Based on the findings, there are three main elements in this stage: implementing lesson plan, utilizing media, and classroom management.

\section{Challenges in Implementing Lesson Plan}

The first element in the execution stage is impementing lesson plan which has been designed before the teaching and learning process. There are 6 respondents who strongly advocated that it becomes something challenging to syncronize the lesson plan and reality in the classroom. Lesson planning is intended to prepare the most effective activities maximizing the time accomodation, as well as to help the teachers in conducting the classroom; making sure that all activities are done. However, in fact, sometimes what we have planned is not entirely well-conducted due to some reasons.

Three PPG graduates teachers stated that one of the reasons why syncronizing the lesson plan and reality became a challenge was students' different ability. Some students might understand the materials faster than the others since the level of children's acceptance of the material varied. Some were interested, some were not which made the implementation is not as smooth as what has been written in the lesson plan. Some of participants also pointed out that sometimes the school agenda 'interfered' the teaching and learning process that has been planned such as school anniversary, guest speakers, workshops, etc. 
Towards the challenge in implemeting the lesson plan, the PPG graduates teachers have offered some responses which they thought to be effective to implement including: controlling emotion, implementing flipped classroom, and creating teachers working group. Some participants believed that the important thing that should be at the very first place was being able to control and manage emotion towards any condition. Sometimes teachers tended to be emotional when some of the students did not pay attention on the activity. The interesting point here was that P6 stated specifically the case that the most challenging time for her was when she got premenstrual syndrome (PMS) that she wanted to be angry for many things. However, she confirmed that as time goes by and the longer the experience of teaching, the more she was able to control her emotions.

Taking into account the teacher's emotional condition, a study conducted by Rodrigo-Ruiz (2016) found that the negative emotions from the teacher, specifically anger, might interfere with the children's ability to process emotional information. In fact, he also stated that teachers' emotions impacted by the student' behaviors in turn could influence the instruction since the instructional quality was worse among the teachers who demonstrated negative emotions and dissatisfaction in teaching as compared to those teachers who showed more positive emotions. In addition, Brackett et al., (2013) ellaborated that the teachers who acted under emotional states of joy, enthusiasim, and optimism while completing the student evaluations gave more positive results than those who were in the state of depression and sadness. Therefore, as P6 mentioned, it was necessary to manage the teacher's emotion to avoid being emotionally unstable role model for the students.

Furthermore, the research subjects who taught in senior high schools suggested the implementation of flipped learning for some sessions. They affirmed that this kind of classroom presented different experience for their students as well as the teachers themselves since it allowed flexible environment and a variety learning models. Flipped learning promoted the classroom time for exploring topics in greater depth and create meaningful learning opportunities while the students were initially introduced to new topics outside the classroom. Correa (2015) ellaborated that since the students had learned the materials before the classroom, the class time concerned on the activities which could increase retention. As the result, the students would find the materials more meaningful since the class time focused on practice (problem-solving) which maximized the opportunities for multiple output.

Referring to the application of the flipped learning classroom, according to Pinto et al., (2016), the new media offered interactivity, instant communication, new spaces, and forms of social interaction (e.g., emails, online games, social networking sites), and tools for media production and sharing (e.g.,video sharing websites, blogs) which could be alternative choices for the teachers to be implemented in their classes. These new media features have led to the media literacy expansion to include the new dimension of production, so basically teachers were helped by the development of the techology. They were able to be already engaged with the students before coming to the classroom, and in the classroom, they only needed further confirmation and deeper explanation without discussing the basic materials which the students have learned outside the class. Therefore, in this case, the flipped learning classroom could be one of the choices for the classroom times interfered by other school agenda.

Besides controlling emotion and implementing FL, three of the research subjects felt that creating teachers working group was very helpful. They stated that the group of English teachers in their school became the place to share opinions, difficulties, experiences, and up-to-date information related to English education. They clarified that the group was basically a forum for teachers in a school as an effort to improve teachers' professional abilities, quality of knowledge, mastery of materials, teaching techniques and others. The main function was to accomodate and solve problems encountered in teaching and learning process through discussion, teaching practises, demontration of the use and the process of making certain media that in the end can create effective teaching and learning activities. This kind of group could be followed by other groups of teachers that functions as supporting system for one teacher to another. By talking to other teachers, they will get new perspectives and advise for limited time to create media, or if it is possible, they can make and use the media together as the effort to minimize time consumption.

\section{Challenges in Utilizing Media}

The second element in the execution stage is media utilization as the supporting component in delivering the materials. There are 6 participants who experienced challenges in utilizing teaching media. They stated that those challenges are in terms of media durability and technology illiterate scchool.

Media durability, based on the findings, focuses on non-digital and digital media. For the non-digital media, the research subjects concerned on whether it is long lasting enough. They stated that the media tend to be easily broken since they are used class to class, touched and used by dozens of students. Furthermore, for the digital media, they highlighted the school's response to the digital media which highly correlate with technology utilization and technology as well. P7, for instance, pointed out:

My school is not really familiar with technology, so it has limited facilities for digital media. In the PPG program, almost all lecturers encourage us to be familiar with new platforms and media that can be applied in the classroom. However, most of the teachers in my school in the end still use conventional way to teach or sometimes there are group works but digital media utilization is rarely chosen due to the limited facilities. 
In the case experienced by P7, the teachers are already aware of the technology development, but the school is not; meaning that it does not support the development whether due to the financial issues or other factors. Important as it may be, according to Persico (2006), the media selection is one of the decisions to be made and it goes hand in hand with the choice of the most suitable strategies for reaching the learning goals. Media are today seen as the tools which the teachers can use for constructing environments that foster and facilitate the learning process. Consequently, although it is probably a challenge for the teachers that the media are easily broken, they are still crucially needed due to their functions and benefits and it is worth to look for the solution. Fortunately, the PPG graduates teachers have provided their way to response to the challenge in utilizing the media.

The research participants asserted that besides reminding the students to use the media carefully, they preferred choosing the best quality materials; using concorde or buffalo paper rather than HVS or art paper, for instance, to make it more solid. Here, they would also automatically consider whether they are easily used in the instructional environment, and what will be the time and the cost in obtaining them. Choosing the best quality materials is actually related to its practicality; whether it is possible for the teachers to provide the media for which they should think and look for the practical media which are easily available in the school or in a shop (if they have to buy the materials). Praticality is one of three factors which should be paid more attention by the teachers before choosing the instructional media, purposed by Baidawi (2016). The other two factors are students' characteristics and instructional activities. It is important for the teachers to consider whether or not the media to be used are appropriate in light of the students' characteristics and should support the activity that will be presented in the classroom.

Another issue in utilizing the media in terms of digital media is the technology illiterate school, although in recent decade the technology utilization has been widely promoted. To address this issue, some of the participants emphasized that they have met the school facilities and infrastructure division to discuss their problem, as an appropriate way since it is an authorized school division concerning on the school facilities. However, while waiting for the school to realize the facilities they purposed, they keep teaching as best as they could using media that was possibly used and accessed in the school. Machanick (2014) discussed this issue in his research which concluded that it was good to have technology in class that can aid the learning, but simply applying technology with no learning model in mind carried risks ike giving students a false impression of learning, or leaving the class behind because it is too tempting to use up all the prepared material. The point was that selecting digital media required technology in which not all schools could fullfil, therefore, the teachers could develop and maximize the class in such a way with the existing facilities.

\section{Challenges in Classroom Management}

The third element in the execution stage is classroom management which according to Sieberer-Nagler (2015) covered six aspects: creating the setting, decorating the room, arranging the chairs, speaking to children and handling their response, developing rules, and communicating the rules to the students. Based on the findings of this research, there are only three of them becoming the research subjects' concerns including: 1) speaking to the students and handling their responses, 2) creating the setting, and 3) groupping the students.

\section{Speaking to the Students and Handling Their Responses}

Seven participants argued that they had some challenges in speaking to the students and handling their responses. They thought that it was not easy to speak fully in English in which some theories may suggest that they have to only use English instead of the L1 for maximization of speaking ability (Ara \& Shorna, 2018). P8, for instance, who has been teaching at one of Indonesia outermost schools for 4 years affirmed that it is even difficult to speak in Bahasa Indonesia only, so she spoke in three languages in her English class: English, Bima langauge, and Bahasa. It somehow becomes a dilemma for the teachers whether they want to have an effective communication with the students by the help of L1 in the target language learning or follow some theories which support the notion that L1 is restricted. In addition, some of them felt less respected while speaking with the students since they are considered as young teachers. The issue of disrespectful students are familiar with teachers. However, Sun and Shek (2012) argued that there is a posibility that it is not only about whether the teachers are young, but such behaviour may indicate that the students lacked proper attitudes and values in interpersonal relationships as well as in their morality. In this case, the teachers' response could define whether they continue being disrespectful.

In responding to the issue of speaking with the students and handling their responses in terms of the use of L1 in the class, the participants pointed out that it was quite impossible to use English all the time in the class, so the L1 assisted them to give confirmation and make sure that the instruction was well-informed. As stated by P8, for example,

\footnotetext{
"Based on my experience, L1 is beneficial to decrease students' anxiety and affective concerns. My students are often unresponsive and unwilling to speak in the class, but when they are allowed to mix their first language in case they do not know how to express the sentence in full English, the opposite circumstance is obtained."
} 
There have been a lot of research and debates among EFL teachers whether using the first language in the EFL classroom where the students have not been able to speak English fluently (as well as understand it) is allowed. According to Khetaguri et al., (2016), it is believed that when learners are exposed to the target language excessively, they will have more practice to develop their language proficiency, for that reason the use of L1 in the language classroom is insistently avoided. Furthermore, Sa'd and Qadermazi (2015) mentioned that one of the major advantages of avoiding L1 in the EFL classes is stated as being the improvement of speaking and listening skills, maximizing students' exposure to English and their becoming accustomed to it. It is supported by Wei (2013) who found the students' progress in English listening and speaking proficiency in the basic and lower-intermediate levels due to the English-only policy.

On the other hand, Debreli (2016) in his research entitled Perceptions of Non-native EFL Teachers'on L1 Use in L2 Classrooms: Implications for Language Program Development found that the teachers were affected negatively and were restricted in certain issues as a result of having to follow strict English-only policies at their institutions. Moreover, Zakaria (2013) in his writing found that a number EFL professionals mentioned that L1 use is beneficial for both the teachers and students as long as it is used in the appropriate times. It is in line with Pan and Pan (2010) who concluded that L1 can be a facilitate tool that will improve the language proficiency of the students as long as it is utilized well and presented communicatively. Another research supporting this finding is a research conducted by Enama (2015) which leads to the conclusion that the use of L1 in the EFL classroom does not hinder learning, rather, L1 is an effective scaffolding tool.

By those two perspectives, the discussion on whether to use the L1 when teaching English has been unable to reach a substantial conclusion. Instead, based on the findings in this study considering the challenges faced, the PPG-graduates teachers confirmed that the use of L1 is beneficial to give additional explanation or confirmation to make sure that there is no misundertanding. The argument stated by P8 is supported by Zakaria (2013) who strongly advocated that L1 is particularly helpful for the teachers when helping the students to engender security, conveying meaning of particular words, checking for comparison, and or explaining grammatical rules. As an additional perspective, Kalanzadeh et al., 2013) in their study found that the teachers who took participation were divided into two groups: those who think that the L1 use is beneficial, and those who think otherwise. However, in conclusion, they decided that the most important point was that the teachers should not be waiting for an ideal class to come since the teachers' effectiveness is when they can make a change in their students' perception and attitudes towards English which can be their benefit, motivate, and support them.

Therefore, on the issue of L1 use, it can be concluded that teachers' role is to always enourage them to utilize English as the main language in the class. Building communication, on how to speak with the students, is one of the crucial parts in English classroom since it discusses language and its use in which the final output is a language production that the students are able to at least speak. The teacher's communication style can influence the interest and attitude of the students in creating a fun and learning atmosphere (Duta, Panisoara, \& Panisoara, 2015). Through the effective communication, the teachers and students collaboratively create a comfortable classroom situation.

The next issue in speaking with the students is that the teachers are less respected due to their young age. It gives similar results to another research conducted by Widiati et al., (2018) that newly teachers tend to face that kind of issue. In this case, the participants stated that they always need to show eagerness, politeness, and availabiliy for their students in order to have an effective classroom environment which helps them in handling the classes, as well as to give them a good role model, no matter how their students are. Having such environment could make them as an effective teachers who are able to maintain their class condition well and handle any kind of responses given by the students where according to Haider and Jalal (2018) friendly nature of a teacher highlights quality relationship with the students. The effective teachers are not only accomplished instructors but also work to understand their students' personalities and needs and to develop and maintain positive supportive teacher-student relationships (Camp, 2011). They are aware of the important differences among students and identifying these differences helps the teacher better understand individual students and permits students to understand that the teacher has a personal interest in them. It then can build harmonious teacher-student relationship and interaction.

\section{Creating the Setting}

A good classroom circumstance is where the students feel welcomed and valued as they are. For optimal learning, they have to feel that the classroom is a 'safe place' where they are able to share their opinions and thoughts without any fear or hesitation (Nusrat, 2017). Therefore, preparing the setting before beginning the teaching and learning process is one of the important things to prepare. However, in practice, there are 6 PPG graduates teachers who experienced the challenge in creating the setting.

These six participants experienced difficulty in handling big classes. P6, for instance, stated, "It is difficult to concentrate on all students in a big class that I think there will be not enough time to pay attention to each of the student and give everyone of them a chance to speak or participate in the activities."

It seems that English teachers have no doubt that large size of classes is a prime impediment for the efficient English teaching and learning. A research conducted by Bahanshal (2013) discovered that all the teachers who participate in the study find it daunting to teach large classes. They point out that despite their efforts to elevate the level of language learning in such context, the outcome of their students is considered to be unsatisfactory. It is due to the fact that there are big numbers of students in one class and all the teachers wish for the number to be reduced. 
With the great number of students enrolling each year in schools and the limited facilities, reducing the class size in some teaching context in Indonesia seems to be impossible. Fortunately, the research participants offer some responses which they think to be effective in addressing this challenge. They allow the students to play an active role in the class and involve them in all decision making about the classroom life as controlling the noise level or other disciplinary actions. It is believed to raise their sense of responsibilities since they are parts of the parties who establish the rules. They also mentioned the students as the active learners, in which the teachers can make the classroom as a collaborative learning class that involves groups of learners working together to solve a problem, complete a task, or create a product (Chandra, 2015). Collaborative learning are basically able to occur peer-to-peer or in larger groups. Similar to the idea that two or three heads are better than one, Chandra (2015) emphasizes that many instructors have found that through peer instruction, students teach each other by addressing, misunderstandings and clarifying misconceptions.

In addition, the majority of the participants also mentioned about giving rewards for positive attitudes and punishment for the negative one. An effective rewards and punishment system can promote positive behavior which are essential foundations to a creative learning and teaching environment (Ching, 2012). The teachers are to choose any kind of rewards to be possibly applied and accepted by the students such as additonal points, special privileges, medals, or gifts. Similarly, the teacher should also communicate the punishment clearly to the students. It can be in the form of point deduction, copying or reciting poems, or oral warning.

\section{Groupping the Students}

Although groupping the students may look simple and easily manageable, there is still challenge experienced by the teachers. Six participants have a similar issue regarding how to distribute the students in a group in order to maximize sharing knowledge outcomes. They stated that the students in their class are naturally groupped to which friend they feel more comfortable. It is somehow not beneficial for the students with low level of understanding since they do not get additional point of views from the students with high level of understanding. Therefore, the students groupping needs to be the teacher's concern as it may influence their output.

Based on the findings, the participants pointed out that the students need to know the reasons why they need to work in group. It would be much easier if they know the objectives and benefits. Working in group offers some advantages such as helping the students to learn from each other, catering better understanding of the content, paving an avenue for the students to solve problems, and providing the students frequent assistance from the group members (Ferdous \& Karim, 2019). Understanding these benefits will allow the students to be more cooperative in working in group. Furthermore, it is going to be more fun if the teachers know how to create the grouping activity as a short yet enjoyable process in the beginning of the task, therefore here, the participants thought that $\mathrm{i}$ is quite effective to make grouping activities fun through simple games and try to make sure that the students do not hesitate to move their body: standing up, moving, minggle with their friends, sometimes with the help of music.

The strategy that participants have done indicate that the teaching and learning activity is not that intransigent. The use of games in grouping is a good start to motivate students to take part in the activities. Gozcu and Caganaga (2016) support this point by stating that games automatically stimulate students interest and can be one of the highest motivating techniques especially in the beginning of the lesson.

The important point is that groupping the students defines how well the process of sharing knowledge and classroom activity will run. The formation of groups that are too homogeneous due to an inadequate distribution of students in groups make it difficult to share knowledge among students. Gorgônio et al., 2017) commited that one of the challenges of every teacher is the difficulty in distributing the students of the class in groups in the most homogeneous/heterogeneous way possible. Therefore, it is necessary to evaluate techniques and methods that assist the teachers in the distribution of students in groups.

\section{Challenges in Evaluation}

According to Maheshwari (2012), evaluation aspect include all the activities which can evaluate the achievements of the students and attainment of the objectives. Teaching is an incomplete process without evaluation. They need to be able to identify and develop appropriate approaches to assessment that will provide the evidence necessary to determine the integrity and trustworthiness of their everyday classroom practices and that will allow their students to make consistent progress in meeting expected learning outcomes (Hollins, 2011). Based on the findings, all of the research participants experienced challenges in evaluation stage in terms of insufficient scores obtained by the students although some remidial tests have been conducted. This phenomenon was commonly experiened by the teachers regarding the school's expectation for the students to get high scores in order to have a good reputation among other schools.

Regarding this issue, the majority of participants suggested to give enrichment materials outside the class hours. P12, for instance, pointed out that he usually gave the enrichment class after reguler class hours. It has been argued by Alghamdi and Siddiqui (2016) that the additional session for the low-achieving students is the form of support to help them not only improving the target language proficiency but also motivation and self-efficacy. It indicates that the enrichment materials are expected to help low-achieving students in getting the best score they could. 
However, after some enrichment materials sessions, they were sometimes still some students who could not reach the minimum score requirement. In this case, the participants confirmed that decreasing the weight of test questions became a choice, since P13 stated, "In this kind of cases, teachers cannot generalize students' abilities. Some students may have different language abilities and we cannot force them to always meet the target."

In addition, as the best preparation that the teachers could do, some participants believed in taking additional score from their daily activities in the classroom. Scoring is not taken from a single task, but the teachers have authority to compile the scores from other possible sources. Therefore, they usually gave the students additional projects and provided them various kinds of activities from which they could take their additional scores. It is in line with Lumadi (2013) research findings which conclude that the expanded opportunity is one of the principles of assessment. It requires the teachers to find multiple ways of exposing the studens to the opportunities that allow them to demonstrate their full potential. The students are expected to succeed, but not neccessarily at the same time and in the same way. Therefore, the teachers need to maximize the opportunity for every student by challenging them to achive and improve as an individual, but not to compete against other students (Lumadi, 2013).

\section{CONCLUSION}

From this study, it can be concluded that the PPG-graduates students experienced some challenges in three phase of teaching and learning process: lesson planning, execution stage, and evaluation; however, along with those challenges, they are able to give responses which they think to be the most effective responses.

For the first phase of teaching that is lesson planning, the participants experienced three issues including selecting media that is related to their financial issues, different formula of lesson plan between schools, and choosing suitable strategies. In challenges of selecting media, the majority of participants suggested to ask the students to take part in the process of making in order to share responsibility and cost. In challenges of different lesson plan formula between schools, the participants had consultation session with senior teachers, re-reading PPG materials, and changing their point of view. In addition, in challenges of choosing suitable strategies, they conducted classroom observation, prepared various strategies, utilized the internet, and became adaptive towards classroom condition.

The second phase is the execution or the implementation stage in which the participants experienced challenges in 3 main elements of the implementation stage: lesson plan implementation, media utilization, and classroom management. In responding the challenges of lesson plan implemenation, the PPG graduates teachers suggested controlling emotion at the very first place, then implementing flipped learning classroom, and creating teacher working group could also be the choice. In media utilization which concerned on the media durability for non-digital media and technology illiterate school in digital media, they created the best quality media to make it long lasting to be used by many classes and discussed with school facilities and infrastructure division in order to help other teachers aware of the development of technoogy in media utilization. Furthermore, the challenges in classroom management covered three main elements: challenges in speaking to the students and handling their responses due to difficulty in implementing English-only classes and less respected young teachers (in which the participants considered the use of L1 with some considerations and showing eagerness, politeness, as well as availability for students who did not respect), challenges in creating the setting (in which they promoted group work and collaborative learning as well as applied rewards and punishment), and challenges in groupping the students (in which they made sure that the students knew the objectives of groupping and played fun groupping games).

Last but not least, the third phase of teaching is evaluation. In this phase, all of the participants experienced challenge of insufficient scores obtained by the students. They then offered three responses which they thought to be beneficial for other teachers who faced the similar situation: providing enrichment materials, decreasing the questions test weight, and expanding the score sources. To sum up, all of the PPG graduates teachers who became the participants in this research experienced some challenges in the three phases of teaching and learning process, but they were able to give responses based on the theories and practices they have got. All of them affirmed that it was because in PPG program they were exposed with many kinds of teaching practices and assignments related to the recent issues in education field.

It is recommeded that the teachers should not give up in any kind of challenges faced since there must be some ways to respond to those challenges appropriately. To all of the teachers-candidates especially who are joining or want to join the PPG program are suggested to maximize the process of learning in the universities or the program since the teaching practices facilitated will be beneficial for teaching in the real classroom. In addition, although it does not become the concern on this research, it was also found that most of the participants give suggestion to the government to conduct monitoring after the program and provide employement school cooperation to help them find the school to teach more easily. Further invertigation is needed in several areas to increase the teachers' capability for planning and managing the classroom activities. As this research mainly gather the data from PPG-graduate teachers focusing on the challenges, further research could cover a wider area to gather the data. 


\section{REFERENCES}

Adanyani, D. P. D. P. (2015). Professional Development for Pre-service Teacher: A Case Study of Professional Development Program for Pre-service Teacher in State University in Central Indonesia (Thesis). Stockholms Universitet, Stockholm, Sweden.

Ahmed, S. (2017). Authentic ELT Materials in the Language Classroom: An Overview. Journal of Applied Linguistics and Language Research, 4(2), 181-202.

Akcan, S. (2016). Novice Non-Native English Teachers' Reflections on Their Teacher Education Programmes and Their First Years of Teaching. PROFILE Issues in Teachers' Professional Development, 18(1), 55-70. https://doi.org/10.15446/profile.v18n1.48608

Al-Azzeh, F. M., \& Yahya, A. A. (2011). Procedures for Evaluating the Teaching Process in Computing Disciplines. International Journal of Emerging Sciences, 1(3), 444-454.

Alghamdi, F. M. A., \& Siddiqui, O. (2016). Supporting Low-achieving EFL Learners: Expectations, Procedure and Significance of Remedial Sessions at a Saudi University. Journal of Education and Training Studies, 4(12), $204-212$. https://doi.org/10.11114/jets.v4i12.2028

Amin, M. Y. M., \& Rahimi, A. (2018). Challenges Faced by Novice EFL Teachers. International Journal of Humanities and Cultural Studies, 5(1), 149-166.

Ara, A., \& Shorna, S. A. (2018). English Only Classroom in EFL Context: A Necessity or A Burden. International Journal of Education, Learning and Development, 6(3), 24-29.

Aslanargun, E. (2015). Teachers' Expectations and School Administration: Keys of Better Communication in Schools. Eurasian Journal of Educational Research, 15(60), 17-34. https://doi.org/10.14689/ejer.2015.60.2

Bahanshal, D. A. (2013). The Effect of Large Classes on English Teaching and Learning in Saudi Secondary Schools. Canadian Center of Science and Education, 6(11), 49-59. https://doi.org/10.5539/elt.v6n11p49

Baidawi, A. (2016). Using Visual Media in Teaching Speaking. Okara: Journal of Languages and Literature, 10(1), 54-65. https://doi.org/10.19105/ojbs.v10i1.811

Bell, J. S. (2002). Narrative Inquiry: More Than Just Telling Stories. TESOL Quarterly, 36(2), 207. https://doi.org/10.2307/3588331

Benson, P. (2014). Narrative Inquiry in Applied Linguistics Research. Annual Review of Applied Linguistics, 34, $154-170$. https://doi.org/10.1017/S0267190514000099

Boikhutso, K. (2010). The Theory into Practice Dilemma: Lesson Planning Challenges Facing Botswana Student-Teachers. Improving Schools, 13(3), 205-220. https://doi.org/10.1177/1365480210385668

Brackett, M. A., Floman, J. L., Ashton-James, C., Cherkasskiy, L., \& Salovey, P. (2013). The Influence of Teacher Emotion on Grading Practices: A Preliminary Look at the Evaluation of Student Writing. Teachers and Teaching, 19(6), 634-646. https://doi.org/10.1080/13540602.2013.827453

Brown, H. D. (2001). Teaching by Principles and Interactive Approach to Language Pedagogy. New York: Longman Inc.

Camp, M. D. (2011). The Power of Teacher-Student Relationships in Determining Student Success. Unpublished Thesis. University of Missouri-Kansas City.

Chandra, R. (2015). Collaborative Learning for Educational Achievement. International Journal of Research \& Method in Education, 5(2), 5. https://doi.org/10.9790/7388-052

Ching, G. S. (2012). Looking into the Issues of Rewards and Punishment in Students. International Journal of Research Studies in Psychology, 1(2), 29-38. https://doi.org/10.5861/ijrsp.2012.v1i2.44

Connelly, F. M., \& Clandinin, D. J. (1990). Stories of Experience and Narrative Inquiry. Educational Researcher, 19(5), $2-14$. https://doi.org/10.3102/0013189X019005002

Correa, M. (2015). Flipping the Foreign Language Classroom and Critical Pedagogies: A (New) Old Trend. Higher Education for the Future, 2(2), 114-125. https://doi.org/10.1177/2347631115584122

Creswell, J. W. (2013). Qualitative Inquiry and Research Design. Thousand Oaks, CA: Sage Publications.

Debreli, E. (2016). Perceptions of Non-native EFL Teachers' on L1 Use in L2 Classrooms: Implications for Language Program Development. English Language Teaching, 9(3), 24. https://doi.org/10.5539/elt.v9n3p24

Dickson, M., Riddlebarger, J., Stringer, P., Tennant, L., \& Kennetz, K. (2014). Challenges faced by Emirati Novice Teachers. Near and Middle Eastern Journal of Research in Education, 2014(1), 4. https://doi.org/10.5339/nmejre.2014.4

Dogruer, N., Eyyam, R., \& Menevis, I. (2011). The use of the Internet for Educational Purposes. Procedia - Social and Behavioral Sciences, 28, 606-611. https://doi.org/10.1016/j.sbspro.2011.11.115

Duta, N., Panisoara, G., \& Panisoara, I.-O. (2015). The Effective Communication in Teaching. Diagnostic Study Regarding the Academic Learning Motivation to Students. Procedia - Social and Behavioral Sciences, 186, 1007-1012. https://doi.org/10.1016/j.sbspro.2015.04.064

Enama, P. R. B. (2015). The Impact of English-only and Bilingual Approaches to EFL Instruction on Low-achieving Bilinguals in Cameroon: An Empirical Study. Journal of Language Teaching and Research, 7(1), 19-30. https://doi.org/10.17507/jltr.0701.03 
Fauzan, F., \& Bahrissalim, B. (2017). Curriculum Analysis Teacher Professional Education Program (PPG) of Islamic Education in Indonesia. TARBIYA: Journal of Education in Muslim Society, 4(2), 148-161. https://doi.org/10.15408/tjems.v4i2.6400

Feldon, D. F. (2007). Cognitive Load and Classroom Teaching: The Double-Edged Sword of Automaticity. Educational Psychologist, 42(3), 123-137. https://doi.org/10.1080/00461520701416173

Ferdous, T., \& Karim, A. (2019). Working in Groups outside the Classroom: Affective Challenges and Probable Solutions. International Journal of Instruction, 12(3), 341-358. https://doi.org/10.29333/iji.2019.12321a

Flores, M. A., \& Day, C. (2006). Contexts which Shape and Reshape New Teachers' Identities: A Multi-Perspective Study. Teaching and Teacher Education, 22(2), 219-232. https://doi.org/10.1016/j.tate.2005.09.002

Gibson, S., \& Oberg, D. (2004). Visions and Realities of Internet Use in Schools: Canadian Perspectives. British Journal of Educational Technology, 35(5), 569-585. https://doi.org/10.1111/j.0007-1013.2004.00414.X

Gorgônio, F. L., Silva, Y. K. N., Vale, K. M. O., \& Silva, H. M. (2017). Grouping Students for Cooperative and Collaborative Learning: Challenges and Trends in Virtual Learning Environments. IEEE World Engineering Education Conference 2(1), 5. https://doi.org/10.14684/EDUNINE

Gozcu, E., \& Caganaga, C. K. (2016). The Importance of Using Games in EFL Classrooms. Cypriot Journal of Educational Sciences, 11(3), 126. https://doi.org/10.18844/cjes.v11i3.625

Haider, A., \& Jalal, S. (2018). Good Teacher and Teaching through the Lens of Students. International Journal of Research, 05(07), 16.

Hakim, A. (2015). Contribution of Competence Teacher (Pedagogical, Personality, Professional Competence and Social) on the Performance of Learning. The International Journal of Engineering and Science, 4(2), 1-12.

Hidayah, I. (2013). Implementation Review of Professional Education of Teachers (PPG) as the Implementation of Quality Management Function. Procedia - Social and Behavioral Sciences, 103, 467-472. https://doi.org/10.1016/j.sbspro.2013.10.361

Hollins, E. R. (2011). Teacher Preparation for Quality Teaching. Journal of Teacher Education, 62(4), 395-407. https://doi.org/10.1177/0022487111409415

Kalanzadeh, G.-A., Hemati, F., Shahivand, Z., \& Bakhtiarvand, M. (2013). The Use of EFL Students' L1 IN English Classes. The International Journal of Language Learning and Applied Linguistics World, 2(2), 30-39.

Khetaguri, T., Zangaladze, M., \& Albay, M. (2016). The Benefits of Using L1 in Foreign Language Learning Process. International Journal of Social Sciences, 2(3), 24-26.

Kunter, M., Klusmann, U., Baumert, J., Richter, D., Voss, T., \& Hachfeld, A. (2013). Professional Competence of Teachers: Effects on Instructional Quality and Student Development. Journal of Educational Psychology, 105(3), 805-820. https://doi.org/10.1037/a0032583

Liu, Y. C. (2014). Perceived Problems of Novice English as a Foreign Language Teachers in Taiwan. International Journal on Studies in English Language and Literature, 2(5), 41-45.

Lumadi, M. W. (2013). Challenges Besetting Teachers in Classroom Assessment: An Exploratory Perspective. Journal of Social Sciences, 34(3), 211-221. https://doi.org/10.1080/09718923.2013.11893132

Mitton-Kükner, J., Nelson, C., \& Desrochers, C. (2010). Narrative Inquiry in Service Learning Contexts: Possibilities for Learning about Diversity in Teacher Education. Teaching and Teacher Education, 26(5), 1162-1169. https://doi.org/10.1016/j.tate.2010.01.001

Öztürk, M., \& Yildirim, A. (2013). Adaptation Challenges of Novice Teachers. Hacettepe Üniversitesi Journal of Education, 28(1), 294-307.

Pan, Y., \& Pan, Y. (2010). El uso de la lengua materna en el salón de inglés como lengua extranjera. Colombia Applied Linguistic Journal, 12(2), 87-96. https://doi.org/10.14483/22487085.85

Pango, A. (2015). Heterogeneous Class and Teaching Practices within the French Course. Journal of Educational and Social Research, 5(2), 53-60. https://doi.org/10.5901/jesr.2015.v5n2p53

Pinto, A., Festas, M. I., \& Seixas, A. M. (2016). Digital Media and the Challenges for Media Education. Applied Technologies and Innovations, 12(2). https://doi.org/10.15208/ati.2016.04

Polkinghorne, D. E. (1995). Narrative Configuration in Qualitative Analysis. International Journal of Qualitative Studies in Education, 8(1), 5-23. https://doi.org/10.1080/0951839950080103

Richards, J. C., \& Bohlke, D. (2011). Creating Effective Language Lessons. Cambridge: Cambridge University Press.

Rodrigo-Ruiz, D. (2016). Effect of Teachers' Emotions on Their Students: Some Evidence. Journal of Education, 3(4), 73-79.

Rodrigues, L. de A. D., de Pietri, E., Sanchez, H. S., \& Kuchah, K. (2018). The Role of Experienced Teachers in the Development of Pre-Service Language Teachers' Professional Identity: Revisiting School Memories and Constructing Future Teacher Selves. International Journal of Educational Research, 88, 146-155. https://doi.org/10.1016/j.ijer.2018.02.002

Sa'd, S. H. T., \& Qadermazi, Z. (2015). L1 Use in EFL Classes with English-only Policy: Insights from Triangulated Data. Center for Educational Policy Studies Journal, 5(2), 159-175. 
Senom, F., Razak Zakaria, A., \& Sharatol Ahmad Shah, S. (2013). Novice Teachers' Challenges and Survival: Where do Malaysian ESL Teachers Stand? American Journal of Educational Research, 1(4), 119-125. https://doi.org/10.12691/education-1-4-2

Sieberer-Nagler, K. (2015). Effective Classroom-Management \& Positive Teaching. English Language Teaching, 9(1), 163172. https://doi.org/10.5539/elt.v9n1p163

Sierra, J. J. (2010). Shared Responsibility and Student Learning: Ensuring a Favorable Educational Experience. Journal of Marketing Education, 32(1), 104-111. https://doi.org/10.1177/0273475309344802

Sulisworo, D., Nasir, R., \& Maryani, I. (2016). Identification of Teachers' Problems in Indonesia on Facing Global Community. International Journal of Research Studies in Education, 6(2). https://doi.org/10.5861/ijrse.2016.1519

Sun, R. C. F., \& Shek, D. T. L. (2012). Student Classroom Misbehavior: An Exploratory Study Based on Teachers' Perceptions. The Scientific World Journal, 2012, 1-8. https://doi.org/10.1100/2012/208907

Triwinarni, E. (2016). Evaluasi Program Pendidikan Profesi Guru (PPG) Pendidikan Agama Islam di UIN Sunan Kalijaga Yogyakarta. Tesis tidak diterbitkan. UIN Sunan Kalijaga, Yogyakarta.

Tsai, H.-C. (2015). A Senior Teacher's Implementation of Technology Integration. International Education Studies, 8(6), 151. https://doi.org/10.5539/ies.v8n6p151

Umar, R., Yusuf, M., Maddatuang, Abbas, I., Basram, N. F., \& Suprapta. (2018). Implementation of SM3T Alumni in Teacher Professional Education Program (Study of PPG SM3T Participants in The Universitas Negeri Makassar). Journal of Physics: Conference Series, 1028, 1-5. https://doi.org/10.1088/1742-6596/1028/1/012207

Wei, D. D. (2013). The Implementation of English-Only Policy in The Tertiary EFL Context IN Taiwan. Indonesian Journal of Applied Linguistics, 2(2), 187-198. https://doi.org/10.17509/ijal.v2i2.164

Widiati, U., \& Hayati, N. (2015). Teacher Professional Education in Indonesia and ASEAN 2015: Lessons 1Learned from English Language Teacher Education Programs.

Widiati, U., Suryati, N., \& Hayati, N. (2018). Unraveling the Challenges of Indonesian Novice Teachers of English. Indonesian Journal of Applied Linguistics, 7(3), 621. https://doi.org/10.17509/ijal.v7i3.9824

Zakaria, F. (2013). The Role of First Language in Efl Classroom. Jurnal Ilmiah Didaktika, 13(2), 373-383. https://doi.org/10.22373/jid.v13i2.484

Zohrabi, M., Torabi, M. A., \& Baybourdiani, P. (2012). Teacher-centered and/or Student-centered Learning: English Language in Iran. English Language and Literature Studies, 2(3), 18. https://doi.org/10.5539/ells.v2n3p18 